\title{
O CONCEITO DE PODER NA CONCEPÇÃO TEÓRICA DE CARL SCHMITT, HANNAH ARENDT E MICHEL FOUCAULT ${ }^{1}$ \\ THE CONCEPT OF POWER IN THE THEORETICAL CONCEPTION OF CARL SCHMITT, HANNAH ARENDT AND MICHEL FOUCAULT
}

\section{Clovis Schmitt Souza ${ }^{2}$}

\section{RESUMO}

O presente trabalho tem por objetivo apresentar as interpretações sobre o conceito de poder na visão de Carl Schmitt, Hannah Arendt e Michel Foucault, autores contemporâneos da área de ciência política. Através do exame das elaborações teóricas dos autores, são apresentados os diferentes revestimentos analíticos desprendidos, suas aproximações e distanciamentos. Por meio do exercício de descrição dos componentes teóricos de cada acepção, será possível notar as diferentes intepretações e compreender, ao fim, como vão servir de lastro as morfologias conceituais que atravessam o conceito no decorrer do debate.

Palavras-chave: ciência política, teoria, Estado moderno.

\section{ABSTRACT}

This work aims to present the interpretations on the concept of power according to the vision of Carl Schmitt, Hannah Arendt and Michel Foucault, contemporary authors in the field of political science. Through the examination of the theoretical elaborations of the authors, the different detached analytical coatings, their approximations and distances are presented. Through the exercise of describing the theoretical components of each meaning, it will be possible to notice the different interpretations and understand, at the end, how the conceptual morphologies that cross the concept in the course of the debate will serve as ballast.

Keywords: political science, theory, modern state.

\footnotetext{
${ }^{1}$ Trabalho de investigação teórico originalmente apresentado no Programa de Pós-graduação em Sociologia Política da UFSC na disciplina de Tópicos Avançados em Teoria Política.

${ }^{2}$ Acadêmico de doutorado do Programa de Pós-graduação em Sociologia Política da Universidade Federal de Santa Catarina - UFSC. E-mail: clovis_sm@yahoo.com.br
} 


\section{INTRODUÇÃO}

O debate a respeito do conceito de poder é central para formulação do campo teórico da ciência política. Dentre as preocupações principais, as investigações questionam as estratégias de ascensão e manutenção do poder por parte do soberano. Nesse sentido, os ensinamentos de Maquiavel na obra O príncipe inaugura o tema.

Embora o debate acerca do marco central de formação do campo teórico da ciência política desperte divergências sobre a inclusão ou não de alguns cânones, há um consenso sob a admissão da obra de Maquiavel para lançar as primeiras bases no debate. Tal fator se justifica pelo aspecto dos compromissos com os acontecimentos históricos que o autor florentino desprendeu para o exame e formulação da sua teoria. Diferente das abordagens dos filósofos gregos Aristóteles e Platão, que nutriam uma concepção da política como um dever ser, Maquiavel apoia suas análises em evidencias dos acontecimentos históricos e se afasta de uma apreciação moral acerca das decisões política de um soberano enquanto corretas ou erradas.

Opondo-se à tradição das antigas virtudes necessárias ao bom príncipe, Maquiavel nega a identificação entre a verdade e o dever fazerem parte da moralidade convencional. Para que o príncipe mantenha o poder, o domínio da aparência é central. Assim, aparentar ser "bom" em oposição a ser "cruel" é uma prerrogativa para manutenção do poder. Sua virtude como regente está na capacidade de ser reconhecido publicamente como justo quando necessário e piedoso quando oportuno.

A obra $O$ príncipe se organiza como um exercício de sistematização de experiências históricas de organização e manutenção do Estado. Como interpretar em cada situação dada qual ato vai corresponder com o sucesso político do príncipe. Assim, cada evento deve ser percebido e respondido segundo os interesses da manutenção do seu poder. Diante disso, o poder para Maquiavel se resume na capacidade do regente manter sob seu domínio a posse exclusiva da capacidade de decisão sobre os caminhos do Estado.

Entre os séculos XVI e XVII uma das principais questões que ocuparam os debates filosóficos foi em torno dos motivos que conduziram os homens a se organizem em torno do Estado e qual a origem legítima de seus governos. É nesse contexto que surgem as teorias contratualistas que postulam um estado de relações humanas livre de qualquer ordem social estruturada, chamada de "estado de natureza", anterior ao surgimento da sociedade civil. No estado de natureza não havia leis ou normas sociais, governos ou obrigações políticas entre governantes e governados. Em um determinado momento os homens sentem a necessidade de criar um acordo, um pacto social (contrato social), através do qual reconhecem uma autoridade (governante) com um conjunto de regras e um regime político.

O contrato social é um instrumento que estabelece os direitos e os deveres. Ele fundamenta o direito dos homens a viver sob o regime de leis através das quais é determinado a cada um o que é seu e assegura-o contra a usurpação por parte de todos os outro. O contrato constitui um meio de 
socialização sob o domínio de um princípio do direito (normativo) que expressa a vontade consensual ou o consentimento racional de todos os participantes. Assim, o contratualismo afasta-se da discussão voltada para o comportamento dos indivíduos no poder, do bom governante ou do governo eficaz, para alçar a reflexão da teoria em direção as instituições e conceber o poder político enquanto entidade autônoma em relação àqueles que a dirigem.

A respeito da discussão do papel das instituições do Estado e sua capacidade de centralização do poder, a obra O leviatã publicada em 1651 por Thomas Hobbes é um marco para análise do papel do Estado Moderno. Segundo o autor, o estado foi formado a partir da dispersão de poder e da relativa anomia do feudalismo medieval. Diante disso, o estado moderno recoloca no centro do palco social duas realidades ao mesmo tempo velhas e renovadas: por um lado as leis civis e por outro lado a figura do soberano.

Hobbes é identificado a partir de uma argumentação que legitima o poder absolutista do soberano ao estabelecer uma distinção entre a posição do soberano e os direitos e deveres dos súditos. O soberano hobbesiano está sujeito somente às leis da natureza, pois essas leis são divinas e não podem ser revogadas pelo poder do estado. Assim, existe uma separação entre os compromissos exigidos para com os súditos de obediência ao poder soberano que está acima das leis e convenções criadas pela sociedade. Logo, o poder que circunda a figura do soberano é prevalente sobre os direitos de vida e morte dos súditos. O poder do Estado é, com isso, a encarnação da figura do soberano.

Como tantas outras conceituações, o poder é motivo de divergência entre distintas correntes teóricas e assume ao longo do tempo um caráter sempre contestável. Como pondera Gallie (1956), conforme os interesses de análise e momentos históricos de pesquisa, o enquadramento teórico contido no exame de um conceito será divergente entre os autores. Desde o marco inicial estabelecido com Maquiavel, passando pela contribuição de Hobbes, a centralidade do conceito do poder serve de inspiração para que novas abordagens ocorram e avanços analíticos sejam apresentados. Animado por este espírito, nosso objetivo com o presente artigo é apresentar um exercício de reflexão a partir de três concepções sobre a temática do poder. Neste propósito será objeto de análise as formulações de Carl Schmitt, Hannah Arendt e Michel Foucault a respeito da ideia do poder e a sua vinculação com a noção de Estado Moderno.

Nosso objetivo é apresentar o exame das contribuições dos autores oportunizando, por conseguinte, uma melhor compreensão a respeito dos possíveis enquadramentos teóricos que gravitam na área, seus usos e recursos. Privilegiamos a escolha desses três autores por seu reconhecido debate para o campo acadêmico e pela qualidade das abordagens ao examinar o poder dentro de um enquadramento de análise que leva em consideração a democracia como instituição de valores que anima a sociedade.

Dado que a política é uma condição humana presente em qualquer época e circunstância, o que está em jogo na administração das relações humanas é o processo de ação política e como o seu exercício garante ou constrange as liberdades. Nesse sentido, os autores reunidos no artigo oferecem 
perspectivas distintas para compreensão da forma pelo qual o poder está relacionado com a organização do Estado Moderno. Assim, como questões de fundo, estamos nos perguntando de que modo às relações na política devem ser nutridas por igualdade entre os indivíduos ou há a necessidade do poder ficar concentrado nas mãos de um soberano ou mesmo qual a possibilidade da identificação de um único local onde esteja o poder? Tais indagações fazem parte do léxico teórico dos autores aqui reunidos.

O exercício de análise inicia visitando a contribuição do jurista Carl Schmitt (2009), que dentre suas preocupações temáticas vai descrever o papel do político no exercício de organização e manutenção do poder dentro do Estado soberano. Como princípio de análise, o autor descreve como a teoria das formas de governo dos pensadores políticos iluministas do século XVIII está fundamentada na legitimação estabelecida entre governantes e governados. A partir disso, Schmitt retoma a tradição da teoria das formas de governo para apresentar sua interpretação a respeito da organização do poder na sociedade. Na sequência do artigo, a filósofa Hannah Arendt alerta sobre os riscos políticos da redução dos indivíduos a meras peças da maquinaria administrativa. O poder não se impõe e nem se sustenta pela violência, pois, para filosofa, o poder surge da ação em concerto dos cidadãos de tal sorte que a violência destruiria as bases de sustentação desse mesmo poder.

O espanto diante da novidade do fenômeno totalitário provocou na autora a necessidade de revisão da tradição do pensamento político ocidental. Nesse sentido, resgata as experiências históricas das cidades-estado antigas da Grécia e chama atenção para as origens do sentido da política que transcende a noção do poder como dominação. Já, para contribuição de Michel Foucault o poder na contemporaneidade não está vinculado única e exclusivamente a figura do Estado, pois o poder é exercido de maneira difusa nos liames da vida dos indivíduos através de processos e práticas sociais que circula, atravessa e penetra no corpo dos indivíduos. Logo, as regras sociais são garantidas pela obediência silenciosa dos indivíduos com a naturalização do poder de "sujeição voluntária".

\section{VISÃO DE SCHMITT SOBRE O PODER NA POLÍTICA}

Entre os autores do período iluminista, a relação do poder passa diretamente pela ideia de identidade e de representação política. Para o pensador inglês Thomas Hobbes (1588-1679), os seres humanos são naturalmente iguais e, por terem excessiva liberdade, lutam uns contra os outros na defesa de interesses individuais, havendo a necessidade de um acordo (contrato) entre as pessoas, a fim de que não se matem. Para evitar a destruição de todos, os membros da sociedade devem renunciar à liberdade e transferir ao Estado o direito de agir em seu nome e coibir todos os excessos.

Para Hobbes a autoridade conferida pela comunidade é depositada na figura do rei. Como efeito, o soberano passa a ser o detentor de todo o poder e será reconhecido como um governante absoluto com a competência de exercer a sua jurisdição sobre todo o corpo social sem prestar contas aos súditos, pois em troca da vida, precisaram entregar a sua liberdade. Todavia, como ilustra Skinner (2005), 
os críticos do absolutismo entendem que não é necessária a existência de um monarca para conduzir ou controlar o Estado, pois este é um corpo social detentor de soberania que pode ser exercido pelos cidadãos integrantes do território.

O embate entre as distintas interpretações contidas na legitimidade do soberano isto é, ser responsável por exercer o poder absoluto ou o poder ser transferido para figura de representantes constituídos pelo corpo político, vai acompanhar o debate entre os autores desse período, e lança luz sobre os princípios de identidade e de representação.

Para John Locke (1632-1704), somente os homens livres e iguais podem fazer um pacto com o objetivo de estabelecer uma sociedade política. Homens livres e iguais são, contudo, todos aqueles que possuem a liberdade de escolha, isto é, exercer sua liberdade de manifestação enquanto indivíduo com direitos e reconhecidos como iguais no interior da sociedade política. Tais princípios serão investigados por Schmitt a respeito da democracia no contexto do Estado Moderno.

Para Schmitt (2009), os princípios de identidade e representação podem ser fundidos através da democracia, pois essa é a forma política de organizar a identidade do povo em sua existência concreta dentro de uma unidade política. Logo, a questão do poder reside na identidade entre dominadores e dominados, governantes e governados, enfim, dos que mandam e dos que obedecem.

Pelo princípio da identidade, Schmitt observa que o Estado é uma organização que contempla a presença de um determinado povo com uma unidade política que se revela dentro de uma vontade nacional. Para o autor, a ideia de vontade nacional acaba por estabelecer a diferença entre os "amigos", isto é, aqueles que pensam de forma semelhante ao seu entendimento e os "inimigos" aqueles que apresentam entendimento diferente. Já o princípio da representação parte da impossibilidade do povo se fazer presente em identidade real nas decisões, por isso se faz representado por representantes políticos.

Seu principal componente está na ordem de definição externas isto é, estão relacionadas com as ações e os motivos políticos, em especial, na diferenciação entre amigo e inimigo. Da mesma forma como as antíteses presentes na moral (bom x mau), na estética (belo x feio) ou na economia (útil x prejudicial), a política é dividida entre a ação dos amigos versus os inimigos. Mas o inimigo, não é em si um atributo principiológico, seu enquadramento deriva de uma tomada de posição dos atores frente a um caso concreto e existencial de conflito declarado.

A ideia que cerca a argumentação de Schmitt (2009), a respeito da definição de político contém uma preocupação de efetivação da política na ordem de resolução de conflitos entre grupos litigantes. Por decorrência, o componente factual do Estado é observado como sendo um Estado total isto é, da identidade entre Estado e a sociedade. Cabe, assim, ao político a função de preservar o "modo de vida" da sociedade através da defesa dos seus interesses até mesmo dentro de um conflito declarado. Por analogia com a noção de guerra, o autor pontua que o conceito mínimo do político reconhece o "outro" como um adversário. Como assevera o autor, 
Inimigo é apenas um conjunto de pessoas em combate ao menos eventualmente, i.e., segundo a possibilidade real e que se defronta com um conjunto idêntico. Inimigo é somente o inimigo público, pois tudo o que se refere a um conjunto semelhante de pessoas, especialmente a todo um povo, se torna, por isso, público." (SCHMITT, 2009, p. 30)

Assim, no espaço público são travados os conflitos entre os adversários com vistas a defesa de interesses frente ao seu oponente. Logo, o que está em jogo na disputa são os interesses de cada Estado (amigo X inimigo) no que se refere a preservação da sua soberania é o reconhecimento da presença de posições divergentes que concorrem para o estabelecimento da conduta a ser seguida pelo Estado.

Desse modo, a estrutura lógica da decisão do soberano descrita por Schmitt apresenta traços claros da concepção de Hobbes, pois as decisões na política devem ser realizadas de forma imune as volições das massas que assumem, por vezes, um tom de "desordem”. Assim, é necessário a presença de uma decisão do soberano como entidade e, com capacidade de orientar a sociedade. Além disso, as considerações de Schmitt se assemelham a postura de Hobbes sob um segundo aspecto: a desvalorização da figura do Parlamento. Ambos compreendem que o parlamento não favorece a tomada das decisões do Estado no sentido que os representantes ficam ponderando exaustivamente sobre distintas posições e isso não é benéfico para tomada de decisão. Assim, um Estado bem conduzido deve ser concentrado nas mãos do soberano. Só cabe a ele o exercício dos dispositivos decisórios.

Segundo Branco (2011), a genealogia da concepção schmittiana das decisões políticas advém do pensamento de Bodin e de Hobbes que produziram o modelo de configuração clássica ao conceito de soberania no qual se apoia o pensamento político moderno. Em certa medida, a concepção política de Schmitt dos anos 1930 é uma resposta ao processo de fragmentação política e despolitização gerada pela ascensão da burguesia e das ideias liberais na Europa. Eventos que introduziram na agenda política novos interesses e interpretações sobre a forma de organizar o poder.

Para Schmitt (2009), não há um fundamento metafísico, teológico ou baseado na moral para orientar a decisão política. Cabe, todavia, as instituições sociais a função de atuarem como um fundamento ou, pelo menos, como um parâmetro às decisões morais. Tal como em Hobbes, para decisão política, não há a necessidade de um fundamento para a autoridade que decide e cria direitos, pois a decisão de estabelecer a alcunha de inimigo ao amigo é derivada de circunstancias que são mutáveis conforme os interesses em jogo. Assim, o Estado deve ser visto enquanto unidade política normativa.

Na análise de Schmitt (2009), acerca do mundo moderno, há uma reflexão a respeito da tendência geral para despolitização e neutralização provocadas pela economia e técnica uma vez que a lógica de funcionamento da economia substituiu a terminologia de adversário (inimigo) pela concepção do negócio entre partes interessadas num dado resultado. Para Schmitt a política é um terreno que deve ser observado pelas lentes do conflito de interesses antagônicos que devem ser gerenciados pela analogia da guerra. De toda forma, o autor não está defendendo que toda ação do Estado é uma ação 
de conflito declarado, mas sim da exigência da postura do soberano ser forte ao defender os interesses do Estado moderno e, este interesse a manutenção da sua soberania.

Doravante há na definição de Schmitt (2009) um teor autoritário na defesa de interesses do Estado. Quando a defesa dos ideais do Estado por parte do dirigente de soberania se estabelece, será licito a conduta de posturas que antagonizem seus adversários, pois a ordem é pressuposta do soberano, sendo suas decisões um princípio absoluto.

A decisão soberana para Schmitt (2009) está fundamentada em uma ordem jurídica que orienta e mobiliza a ação política. Nesse sentido, a democracia enquanto forma de governo não se opõe necessariamente à ditatura, nem se define a partir da liberdade. Para o autor, pode haver ditadura com democracia, ditadura sem democracia e democracia sem liberdade, mas o que não pode ocorrer é o "eterno diálogo" isto é, em dado momento deve ser cessado o espaço de debate e deliberação na sociedade frente às exigências necessárias para a tomada de posição. Nestes termos, cabe ao político o ônus da tomada de posição para sociedade e seu direcionamento.

Para Branco (2011), a filosofia política de Carl Schmitt provoca aversão e ao mesmo tempo atração em seus leitores, pois apresenta uma interpretação realista a respeito da organização da política, onde as peças do tabuleiro se movimentam numa perspectiva real. Cada peça é mobilizada conforme o interesse do soberano no front de batalha. Assim, o político, para obter ganhos reais não está, por vezes, inclinado para produção de uma paz na humanidade, através dos ganhos advindos da capacidade comunicativa ou da disposição ao diálogo entre "cavalheiros" honrados ${ }^{3}$. Schmitt expõe as vísceras do jogo político, o que está em tela é o conflito aberto e declarado entre posições divergentes. Quem apresenta a melhor estratégia, vence a disputa. Neste sentido, embora não seja objeto de reflexão no presente exercício de síntese teórica, há uma vinculação entre os elementos conceituais de Carl Schmitt e sua forma de compreensão do poder e os desdobramentos que sua vida vai percorrer no contexto da Alemanha nazista.

Segundo Branco (2011), a adesão de Schmitt ao partido nazista no ano de 1933 foi acompanhada pelas funções de conselheiro de Estado na Prússia que vai exercer para o Reich ${ }^{4}$. Não obstante a isso, no que pese ao seu aspecto teórico e político, Schmitt foi um intelectual que via com preocupação a ascensão do poder tanto do lado nacional socialista alemão quando bolchevista da Rússia.

Neste enquadramento histórico e político, as contribuições da filosofa Hannah Arendt a respeito dos mecanismos de ascensão do totalitarismo por meio do exercício político do poder apresenta

\footnotetext{
${ }^{3}$ Carl Schmitt se opõe ao modelo procedimental da política deliberativa proposta por Habermas (1995). Habermas ao criticar a concepção liberal e a republicana a respeito dos processos democráticos vai sugerir um modelo deliberativo para estrutura da democracia. A proposta do autor parte do principio da importância da formação de uma base social que ocupe os espaços públicos de maneira horizontalizada. Assim, todos os cidadãos ao pactuarem pelo direito a liberdade dos indivíduos apresentarem seus argumentos na arena pública, os elos da democracia seriam fortalecidos. Todavia, para que isso ocorra satisfatoriamente o processo de colonização dos saberes realizado pelos indivíduos dotados de condições técnicas deve ser combatido pelo lastro jurídico.

${ }^{4}$ A colaboração de Schmitt para o regime de Hitler finda no ano de ano de 1936 quando é perseguido pelos agentes da SS.
} 
uma concepção equidistante das ponderações de Carl Schmitt. Com essa breve consideração, damos prosseguimento ao exercício de análise com a descrição da visão de Hannah Arendt a respeito do poder na sociedade moderna.

\section{VISÃO DE HANNAH ARENDT SOBRE O PODER NA POLÍTICA}

A filósofa Hannah Arendt observa a política como um espaço de exercício de poder para o qual a esfera pública deve constituir-se como um valor social a ser compartilhado por todos os indivíduos que fazem parte da sociedade. Assim, quando a autora recupera o modelo de organização política adotado na Grécia de Péricles, nota como a noção de participação na vida pública ateniense germina com o desenvolvimento dos valores sociais de participação na vida política.

O cidadão fornece a base de legitimação das soluções propostas e executadas. Reunidos em grandes assembleias, participavam de todas as decisões que diziam respeito ao bem comum, sobre o que seria uma boa vida, etc. Para saber se Atenas deveria ou não atacar o inimigo, não seria preciso consultar um especialista ou de um profissional para justeza das decisões. Estas estavam ligadas aos negócios humanos, as atitudes humanas e, portanto à política da cidade, entendida como a arte do diálogo, da opinião e da persuasão. Nisso, o critério de verdade do justo, do virtuoso, era sua aceitação em praça pública.

Essa inspiração nutriu as considerações de Hannah Arendt ao formular sua reflexão acerca da importância da manutenção do espaço público como local no qual os indivíduos aprendem a política e o seu exercício de exposição de ideia. Para tanto, Arendt (2007) se apoia no modelo narrado por Homero em sua teodicéia a respeito dos feitos heróicos da Grécia, para tecer sua concepção da filosofia política como um campo valorativo que deve orientar a vida dos indivíduos em sociedade. Assim, sua análise parte da recuperação dos ideais gregos de participação na vida pública como chave explicativa para o exercício da vida nas democracias modernas 5 .

Nesse sentido, o mito do herói é um arquétipo social que revela um propósito muito maior a ser desejado pelos homens. Por exemplo, a busca de Aquiles pela glória coloca em evidência a entrega do herói para causas maiores que a finitude da vida singular. Sua felicidade (eudaimonia), isto é, o caminho da virtude está contido na capacidade de viver em direção a um propósito; da entrega da sua vida para defesa dos princípios e valores defendidos pela sociedade. Seu oposto será uma vida sem heroísmo (sem virtude).

Para Arendt, a esfera pública é um espaço no qual o embate entre ideias distintas se digladiam na busca da resolução dos dilemas políticos. A omissão em participar deste ambiente de convívio

\footnotetext{
${ }^{5}$ Quando observamos a estrutura política da Grécia do século V é perceptível que noção de participação na vida pública ateniense era um direito concedido apenas a uma pequena parcela da sociedade. Da vida política eram excluídos as mulheres, os estrangeiros e os escravos, mas, não obstante a tudo isso, é inegável identificar na cidade-estado grega a presença dos primeiros passos para o desenvolvimento dos valores sociais de participação na vida política.
} 
político permite que a erva daninha da tirania germine e, com ele o poder tende a fenecer. Por isso, quando o indivíduo vive somente para vida privada (oikos) está abdicando da glória que reside na defesa de valores maiores que a mesquinharia da vida privada.

Assim, as vantagens aparentes da tirania como estabilidade, segurança e produtividade conduzem para perda do poder. Logo, a liberdade através da ação política dos indivíduos é a vitalidade da sociedade. Pois, o poder só se efetiva quando a palavra e o ato estão integrados. Quando ocorre o divórcio entre os termos, a tirania se instala e impede o desenvolvimento da esfera pública.

Além disso, a dignidade da política está contida na capacidade de produção do discurso. $\mathrm{Na}$ modernidade, sob os auspícios do homo faber foi instalado a crença de que o discurso deve possuir uma dimensão da utilidade funcional. Assim, a dimensão da operacionalidade da vida na sociedade vai esterilizando o solo do espaço público e substituindo-o pelo mundo da produção de mercadorias.

A forma de convivência vai perdendo a compreensão do debate, da deliberação entre os indivíduos e, como resultado ocorre o isolamento dos indivíduos que alienados não têm a mesma habilidade de participar na vida política. Como assevera a autora,

Foi nessa ausência de relacionamento humano e essa preocupação fundamental com mercadorias permutáveis que Marx denunciou como a desumanização e auto-alienação da sociedade comercial que, de fato, exclui os homens enquanto homens e, numa surpreendente inversão da antiga relação entre público e privado, exige que eles se revelem somente no convívio familiar ou na intimidade dos amigos (ARENDT, 2007, p. 222).

Para Arendt (2007), na modernidade deve existir uma igualdade política entre todos os indivíduos. As diferenças contidas nas atividades ocupacionais não são em si mesmo um problema para o desenvolvimento da igualdade, pois todos os trabalhadores compartilham da noção de igualdade como cidadãos. No encontro entre as diferenças, a condição humana se estabelece como princípio de vida política.

Neste sentido, a autora se opõe ao entendimento de Platão que estabelece uma diferença central entre quem sabe e dá ordens e quem não sabe e recebe ordens. Nessa concepção da política, ocorre a exclusão da própria noção de esfera pública, pois não ocorre o processo de discussão entre todos os indivíduos da sociedade. As decisões ficam restritas aos integrantes da elite intelectual ${ }^{6}$.

Para Arendt, o poder surge quando os indivíduos se reúnem e "agem em concerto" no espaço público. A união, a integração será o resultado da convergência dos indivíduos para um mesmo propósito onde acordos são assumidos. Com isso, a condição humana decorre da capacidade dos indivíduos envolvidos numa determinada sociedade assumirem acordos. Não se baseia simplesmente no bom caráter de líderes políticos sendo, antes disso, códigos de conduta compartilhados, tornando-se senso comum dentro de uma comunidade ou sociedade no qual são aceitos, respeitados e impostos

6 Para Platão, a atividade de pensar era privilégio de uns poucos que detinham talento, tempo e dinheiro para se dedicar a busca de respostas para vida em sociedade. Assim, a política passa a ser assunto dos filósofos e não mais dos cidadãos. 
por seus membros. Assim, o exercício do poder é o resultado da imposição de certos valores que devem orientar a conduta dos indivíduos. Como uma narrativa e sentido de propósito de vida, o espaço público deve ser preenchido pela vitalidade do ato de tolerar a divergência.

Arendt (2007), reflete como foi possível que modernamente os países que apresentam uma trajetória de regime democrático vão sucumbir ao totalitarismo. Assim, indaga sobre quais seriam as condições oportunas para a ascensão dos regimes totalitários como o apresentado pela Alemanha nazista. Com a obra "A origem do totalitarismo" (1989), percebe-se como o isolamento dos indivíduos e o seu afastamento da esfera pública vai permite a germinação das atrocidades perpetradas pelos nazistas, como também o estado total de isolamento político vivido pelas massas na democracia moderna.

Neste sentido, Arendt (2007), desenvolve o conceito de vita activa como sendo o expoente necessário para a realização das atividades do homem com o mundo. Trata-se de uma forma de dissipar a "alienação no mundo moderno" que torna o isolamento uma experiência diária das massas em busca da participação no espaço público como a vitalidade da sociedade, pois o poder está presente quando os indivíduos participam da vida política.

A semelhança da filosofa, outro conterrâneo seu aposta nos princípios da racionalidade e capacidade explicativa para organização o debate no espaço público. Para Habemas (2000), o ideário do esclarecimento atribuído à esfera pública exerce o papel da emancipação social através do engajamento de todos os indivíduos na política. Assim, o poder no Estado Moderno está localizado na condição dos indivíduos ocuparem o espaço público e exercerem socialmente seu direito de liberdade e manutenção dos consensos no "mundo da vida".

Através do uso da linguagem é possível ativar os discursos que levem aos consensos sociais e assim o poder fortalecer o espaço público com um ambiente de resolução de divergências, produção de consensos e estabelecimento de ideais comuns. Logo, é através do diálogo permanente no espaço público que o poder se manifesta e ganha musculatura contra as paixões ditatoriais e tirânicas que pode atravessa o interesse de particulares, pois a exposição pública exerce o papel de controle da vontade individual.

\section{O PODER NA ELABORAÇÃO DE MICHEL FOUCAULT}

Para Foucault, o medo é um importante ingrediente a favor do Estado e seus mecanismos de justificação de legitimação. Durante o período identificado pelo autor como clássico da humanidade, o poder do soberano era "teatralizado" na praça pública através de expedientes como a crueldade, a tortura e o suplício dos indivíduos considerados como desviantes das regras de autoridade do Estado. Nesse período, o poder é identificado como um elemento "externo" que serve de suporte para legitimar e naturalizar os acordos em sociedade. Assim, através da punição, o soberano exerce seu poder e tem na prisão um importante aliado. 
Na modernidade, contudo, ao invés da teatralização do suplício e do espetáculo público da punição, temos o advento quase do seu contrário, pois o suplício passa a ser tido quase como sinônimo de “desumanidade". Contudo, como ilustra Foucault (2004), a mudança de chave do exercício da punição só altera seu expediente, sai de cena a figura do carrasco com sua face coberta pelo capuz e de posse do machado em punho pronto para seccionar as partes do corpo de qualquer indivíduo que ouse questionar o poder do soberano, para adentrar ao palco da vida social novos mecanismos disciplinares.

A "vantagem" do novo momento histórico é que o poder passa da condição "externa" para uma condição "interna" aos indivíduos. Através dos símbolos utilizados pelo Estado como o uso as bandeira com as cores do soberano, do pagamento de tributos e o permanente medo de invasões, por exemplo, os súditos são ensinados a obedecer e respeitar os interesses do soberano com a naturalização de um processo disciplinar que paulatinamente foi internalizado nas rotinas da vida dos indivíduos.

Assim, a dominação sofre uma mudança estrutural, pois o poder do Estado passa a exerce o seu controle social por meio de uma nova forma. A poder passa a ser exercido não mais sobre o “corpo", mas sobre a "alma" dos indivíduos. Isto é, a "alma" dos indivíduos é disciplinada não mais através de dispositivos externos como as prisões exclusivamente. O processo de disciplina se alastra por toda a sociedade e vai abranger também as fábricas, as escolas, os hospitais, os tribunais assim como todas as instituições sociais presentes na modernidade.

Trata-se da autoridade do soberano sendo exercido como uma espécie de "microfísica do poder". De caráter difuso e de difícil percepção, as diversas instituições sociais presentes na sociedade moderna propagam os preceitos morais de uma engenharia da dominação.

A produção da nova tecnologia do Estado para legitimação do seu poder age no corpo através da construção de indivíduos com uma dupla característica: um corpo dócil no sentido do indivíduo não ter consciência da sua própria condição de submissão e um corpo produtivo ao entregar sua energia para manutenção dos interesses do Estado. Nesse sentido, o poder é eficiente na medida em que tem como garantia o consentimento do indivíduo que participa da dominação ao qual está submetido. Tem-se, o poder como uma instância social que mobiliza a adesão dos indivíduos, pois o poder se perpetua e se renova através de dispositivos sociais presentes na sociedade.

Segundo Foucault (1999) o poder assume um discurso de verdade que traz consigo efeitos específicos com condições de julgar, condenar, classificar ou mesmo obrigar o dominado a viver com determinada forma. Todavia, não se trata de discussão acerca de uma dominação global de um ente sobre outro ou de um grupo específico, mas das múltiplas formas de dominação que podem se exercer no interior da sociedade.

A formulação teórica do autor diz respeito às múltiplas sujeições que ocorrem e funcionam no interior do corpo social. Neste sentido, o aspecto metodológico proposto orienta que o pesquisador não deve procurar o poder no âmbito do edifício jurídico da soberania, dos aparelhos do Estado ou das ideologias que o acompanham, é necessário conduzir a investigação para os operadores materiais, 
para os processos de sujeição e dos dispositivos do saber, pois é preciso se desvencilhar do modelo do Leviatã descrito por Hobbes posto que, nos termos do autor,

[...] desse modelo de um homem artificial, a um só tempo autômato, fabricado e unitário igualmente, que envolveria todos os indivíduos reais, e cujo corpo seriam os cidadãos, mas cuja alma seria a soberania." (FOUCAULT, 1999,p. 40)

Trata-se de um poder não soberano, mas sim disciplinar. Um poder que reside no discurso produzido pelos aparelhos do saber em seus múltiplos campos do conhecimento. Na Idade Média esse discurso de poder era vocalizado pela Igreja, que tinha as condições de constituir e reconstituir os agentes, através das designações utilizadas (por exemplo, através do termo herege ou bruxa que já exerciam a sujeição àqueles assim classificados). Após, a medicina vai igualmente exercer esse dispositivo de controle ao enquadrar os indivíduos como doentes ou loucos. Com a modernidade, os dispositivos discursivos utilizados pelo direito exercem também essa dominação, através da produção de novos discursos com a capacidade de constituir valorativamente os agentes.

Na reflexão de Foucault não ocorre, contudo a reprodução de um discurso institucionalizado, mas da vocalização de um discurso instituído pela norma, pela normalização dos termos de dominação. Assim, através da normalização dos procedimentos e das técnicas da disciplina, os discursos colonizam os atributos da lei. Como resultado, o poder se exerce e se renova por todos os períodos da humanidade.

A centralidade do poder deixa de ser procurada na presença de um ente soberano como o Estado e seu exercício de análise se transfere para todos os espaços da vida societária. Tem-se, com isso, um desafio ainda maior para a adequada compreensão do conceito de poder, pois é exercido com auxílio das sutilezas das relações sociais e está contido em todos os espaços onde os sujeitos são produzidos.

\section{CONSIDERAÇÕES FINAIS}

As considerações teóricas a respeito da utilização do conceito de poder é uma referencia básica embora essencialmente contestável no campo disciplina da ciência política. Parte disso decorre de uma dimensão epistemológica que atravessa a forma de olhar e interpretar a realidade social conduzida pelos autores. Outra parte deriva do fato de que os conceitos são embalados por definições que procuram responder perguntas sempre renováveis. Assim, o desafio do artigo foi reunir três autores posicionados em escolas diferentes, mas que nutrem como denominador comum a preocupação com o exercício do poder no Estado Moderno.

As diferenças identificadas em cada vertente teórica possibilitou compreender como um conceito pode ser percebido em diferentes tonalidades e revela, com isso, distintas interfaces do mundo social. Uma vez que nenhum conceito é estanque e imutável, seu entendimento se presta sempre a ser posicionado e reposicionado a serviço de responder as perguntas que se renovam a cada momento da 
história. Diante disso, a capacidade de mapearmos as diferentes tradições teóricas além de ampliar nosso repertório de reflexões, possibilita que o exercício da investigação teórica se renove cotidianamente.

O exercício descritivo de compreensão de um autor renova o desafio de percebermos o que há de atual na sua contribuição. Nesse sentido, o itinerário proposto no artigo procurou verificar como o conceito de poder foi estabelecido por Carl Schmitt, Hannah Arendt e Michel Foucault em parte de suas obras. Arendt é notadamente identificada com uma base aristotélica e produziu uma crítica a modernidade enquanto ideário de vida, já Schmitt adota uma visão moderna com forte inspiração em Hobbes para discutir os limites da soberania do regente no exercício do poder. Enquanto Foucault está alinhado com a tradição da pós-modernidade e vai investigar como os mecanismos de poder vão, ao longo da história, se deslocar dos aparatos do Estado na direção das microesferas de poder administradas pelos indivíduos em suas múltiplas condutas e faces sociais.

Como vimos, a contribuição de Michel Foucault tomou o contexto do poder como um indicativo da produção de processos de desigualdade, através do processo de disciplinamento. O poder em Foucault não é visto como substantivo, como expresso na obra de Arendt, e sim como um adjetivo. Isto é, o poder é uma faculdade de produção de desigualdade exercido para fins de manutenção das diferenças, de tal sorte que o dominado não percebe sua condição de subalternidade.

Logo, se para Arendt (2007) a presença do poder fica expresso na capacidade da vinculação da palavra em ato e tem como suporte a arena do espaço público, o exercício do poder ocorre no espaço público e é exercido pelo indivíduo. Todavia, como alerta Habermas (2000) todo processo de debate e busca de convencimento pela exposição de ideias no espaço público corre o risco do senso comum, da doxa ou mesmo da colonização por parte dos indivíduos que estejam dotados de algum tipo de fator diferenciador que faça com que sua presença tenha a capacidade de inibir e provocar consensos não pelo convencimento, mas pela imposição da ideia de particulares?.

Nesse sentido, o risco do espaço público ser ocupado encontra eco com as indagações de Foucault (1999), pois o poder é fator de diferenciação dos indivíduos. Assim, o espaço público não deve ser entendido como uma arena no qual os indivíduos recorrem de maneira livre e desinibida de interesses e diferenças. Quando os interesses são confrontados, cada um faz uso do seu repertório com o propósito de obter os maiores ganhos possíveis. Assim, o poder está presente em todas as manifestações da vida em sociedade e opera com auxílio dos dispositivos de saber que produzem dominação.

Logo, o espaço público representa apenas mais um local no qual o poder pode se manifestar pela condução dos indivíduos. Por exemplo, o poder exercido pelos sofistas época das cidades-estado

\footnotetext{
${ }^{7}$ Para Habermas (2004), verdade é um procedimento. Para ser alcançada é necessário que os sujeitos admitam certos critérios de apresentação dos argumentos isto é, a administração de condições formais no qual exista uma "situação ideal de fala" no qual ocorram algumas garantias de procedimentos como: 1) igual oportunidade de emprego de fala; 2) igual oportunidade de formulação de interpretações, afirmações, recomendações, explicações, justificativas, etc; 3) produção do discurso que admita falantes com oportunidades iguais. Trata-se de um conjunto de condições que devem ser respeitadas no espaço público para que exista uma ética do discurso.
} 
gregas mostra como as ideias virtuosas da vida pública pode ser "colonizada" pelos interesses dos mais habilidosos na tarefa de produzir um discurso aceito como verdade.

Contudo, quando decisões política são retiradas da ágora e levadas exclusivamente para figura da representação, não há garantias de que as decisões sejam melhores que as decisões produzidas em espaços públicos menos institucionalizados. Como expõe Foucault, o poder provoca as assimetrias e está presente em todas as relações sociais humanas. Esse modo de perceber o funcionamento do poder moderno é diametralmente oposto à forma dominante tanto para a consciência cotidiana quanto para as ciências afirmativas do mundo para as quais o Estado teria o monopólio do poder na sua relação com os cidadãos.

A modernidade se funda na promessa emancipadora de um soberano cujo compromisso de proteção cala o cidadão da vida pública e do risco de uma guerra de todos contra todos. Sendo o homem o lobo do homem, somente um soberano protetor poderia dar a garantia de sobrevivência num mundo de cidadãos obedientes, infantilizados pelo medo e desejo de proteção.

A interpretação de tradição contratualista evocada por Schmitt compreende como central no exercício do poder a figura do Estado. Contudo, a luz das considerações de Foucault, tal visão é míope em relação ao jogo de interesses e influencias que pré-decidem e antecipam aquilo que depois se torna explicito como política. Assim, o poder diferente da reflexão de Schmitt (2009) não está contido no soberano enquanto homem, que encarna os interesses do Estado. O poder circula, o poder transita entre os indivíduos, pois não há um único lugar onde está contido.

Na modernidade muda a escala e a amplitude do processo de disciplinarização. A perspicácia do exercício do poder nesse novo momento torna os processos disciplinares como uma lógica principal de funcionamento de toda a sociedade. Além disso, acrescenta-se o fato de que o processo disciplinar passa a ser percebido como de "interesse" do disciplinado, dado que as possibilidades abertas pelo poder envolvem todos os processos e constrangem as resistências dos indivíduos frente a um poder que está diluído em todos os processos da vida social.

O poder na contemporaneidade fica afixado em sua forma mais explicita nos operadores do Estado ou de maneira mais diluída, com olhos que controlam e punem o indivíduo sem que este tenha condições de saber as motivações para o seu julgamento. Esse Estado com tentáculos é o Leviatã moderno que constrange e diminui as condições de operação da liberdade dos indivíduos. Nesse sentido, como forma de resistência a condição de constrangimento do Estado, o indivíduo deve, seguindo os preceitos descritos por Hannah Arendt, não abandonar o espaço público, pois ao renunciar a liberdade das ruas está oferecendo o seu pescoço para que o carrasco manipule o machado para seccionar a sua vida, a sua liberdade. 


\section{REFERÊNCIAS}

ARENDT, Hannah. A condição humana (capítulo V - Ação). 10 ed. Rio de Janeiro: Forense Universitária, 2007.

Origens do Totalitarismo. São Paulo: Companhia das Letras, 1989.

BRANCO, Pedro Hermílio Villas Bôas. O papel do Estado na filosofia política de Carl Schmitt. In: O que faz nos faz pensar. n. 30, 2011.

FOUCAULT, Michel. Em defesa da sociedade (Aula de 14 de janeiro de 1976). São Paulo: Martins Fontes, 1999.

. Vigiar e punir: nascimento da prisão. Petropolis: Vozes, 2014.

GALLIE, Walter. Essentially contested concepts. Proceedings of Aristotelian Society. v. 56. 1956.

HABERMAS, Jurgen. O discurso filosófico da modernidade. São Paulo: Martins Fontes, 2000.

Verdade e Justificação: ensaios filosóficos. São Paulo: Edições Loyola, 2004

MACEDO Jr. Ronaldo Porto. Constituição, soberania e ditadura em Carl Schmitt. In: Lua Nova, n. 43. São Paulo, 1997.

SCHMITT, Carl. O conceito de político. Belo Horizonte: Del Rey, 2009.

SKINNER, Quentin. Significação e compreensão na história das ideias. In: Visões da Política: sobre os métodos históricos. Algés: Difel, 2005. 
